\title{
KRITIK TERJEMAHAN: SEBUAH PENGANTAR PENDEK
}

\author{
M. Zafrialdi \\ English Department, Faculty of Language and Culture, Bina Nusantara University, \\ Jln. Kemanggisan Ilir III No. 45, Kemanggisan/Palmerah, Jakarta Barat 11480
}

\begin{abstract}
Article presented the role and function of translation critics, preceded by analyzing a difference of translation results based on the men's jobs, continued by clarifying the meaning and role of translation critics, translation analysis as one aspect in tranlation critics, and efforts to involve translation critics in education. It is concluded that translation critics is a bridge that correlate translation theory dan its practice, the importance of the critician.s attitude and his knowled in translation, the ability of a translation critician in comprehending and analysing the output of translation, and the advantage of involving translation critics in education.
\end{abstract}

Keywords: translation critics, short introduction

\begin{abstract}
ABSTRAK
Artikel menjelaskan peran dan fungsi kritik terjemahan yang dimulai dengan suatu ilustrasi tentang beda hasil terjemahan berdasarkan profesi beberapa orang, dilanjutkan dengan penjelasan arti dan peran kritik terjemahan, penilaian terjemahan sebagai salah satu aspek dalam kritk terjemahan, dan upaya memasukkan kritik terjemahan dalam dimensi pendidikan. Disimpulkan bahwa kritik terjemahan adalah jembatan yang menghubungkan antara teori dan praktik terjemahan, pentingnya sikap dan pengetahuan tentang kritik terjemahan, kemampuan seorang kritikus terjemahan untuk memahami dan menganalisis karya terjemahan, dan keuntungan memasukkan kritik terjemahan ke dalam program pendidikan bahasa.
\end{abstract}

Kata kunci: kritik terjemahan, pengantar pendek 


\section{PENDAHULUAN}

Konon seorang mahasiswa bahasa melakukan survei sederhana yang berkaitan dengan bahasa. Dari berbagai macam cara dan bentuk pengambilan data yang digunakan, salah satunya adalah dengan membagikan sebuah teks yang berupa sebuah kalimat Bahasa Inggris kepada tiga orang yang ia nilai mempunyai kemampuan Bahasa Indonesia dan Bahasa Inggris yang sangat baik dengan berbagai latar belakang yang berbeda.

Ia minta kepada tiga orang tersebut untuk menerjemahkan sebuah kalimat yang berbunyi: “Tsunami has killed millions”. Teks tersebut ia dapatkan dari sebuah majalah internasional terkenal. Kemudian ketiga orang tersebut menerjemahkan teks tersebut dan segera menyerahkan terjemahannya kepada si mahasiswa.

Setelah membaca tiga terjemahan tersebut, si mahasiswa merasa heran karena ternyata terjemahan dari ketiga orang tersebut berbeda satu dengan lain. Berikut adalah terjemahan mereka.

Teks Asli:

Tsunami has killed millions

Teks Terjemahan:

(orang 1): --- Tsunami telah membawa korban jutaan nyawa manusia.

(orang 2): --- Musibah Tsunami telah menghilangkan jutaan jiwa manusia.

(orang 3): --- Tsunami telah membunuh jutaan jiwa

Yang paling menjadi perhatian si mahasiswa adalah bagaimana masing-masing orang menerjemahkan verba "killed" dengan padanan yang berbeda. Di tengah keheranannya, si mahasiswa kemudian menanyakan kepada ketiga orang tersebut mengapa mereka menerjemahkan dengan cara yang berbeda. Setelah mendengar penjelasan dari ketiga orang tersebut, maka si mahasiswa akhirnya mengerti mengapa terjemahan mereka bisa berbeda.

Orang pertama adalah seorang wartawan paruh waktu. Dia menerjemahkan kalimat Bahasa Inggris tersebut dengan: 'Tsunami telah membawa korban jutaan nyawa manusia'. Dia menerjemahkan verba "killed" dengan bentuk "membawa”. Dia menjelaskan bahwa bentuk "membawa" merupakan pilihan kata yang paling tepat karena dianggap paling netral. Sangat sesuai untuk teks yang bertujuan untuk memberikan informasi.

Penerjemah kedua adalah seorang agamawan. Terjemahannya adalah: 'Musibah Tsunami telah menghilangkan jutaan jiwa manusia'. Dia mengatakan bahwa dia sengaja menambahkan kata "Musibah" sebelum kata "tsunami” dan menerjemahkan verba 'killed' dengan bentuk 'menghilangkan' karena menurutnya tak ada kejadian di dunia ini bisa terjadi tanpa seijin Tuhan. Dia yang menyusun hukum alam dan Dia yang memberi ijin hukum itu berjalan. Sekelompok semut bisa berhasil membangun sebuah sarang karena ada ijin dari Dia. Apalagi sebuah Tsunami hebat, tak mungkin terjadi jika Tuhan tak menghendaki. Dia mengijinkan dan menghendaki dengan cara yang unik. Dia mengijinkan dalam menghendaki dan Dia menghendaki dalam mengijinkan. Dia Maha Besar dan Maha Kuasa. Demikian agamawan tersebut berfilsafat tentang Tuhan dan peristiwa alam.

Oleh karena itu ia berpandangan bahwa terlalu dangkal jika memandang tsunami hanya sebuah peristiwa alam semata. Tsunami adalah 'musibah' dan itu adalah ujian dari Tuhan. Dan menurutnya, sungguh sangat tidak pantas di dalam sebuah ujian dari Nya ada yang disebut dengan 'korban'. Oleh karena itulah ia tidak memunculkan kata 'korban' dalam terjemahannya. Dan bisa diduga, ini membawa kepada konsekuensi logis berikutnya yaitu penggunaan bentuk 'menghilangkan' untuk menerjemahkan verba 'killed'. 
Sekarang tibalah orang ketiga memberikan penjelasan. Dia adalah seorang pujangga dan dia menerjemahkan dengan bentuk 'Tsunami telah membunuh jutaan jiwa'. Yang menarik di sini adalah dia menerjemahkan bentuk 'killed' dengan padanan 'membunuh'. Menurutnya, bentuk 'membunuh' harus dan wajib dimunculkan dalam teks terjemahan demi mempertahankan vitalias dan muatan emosi yang ada pada teks asli. Dia beranggapan bahwa penulis sengaja memilih bentuk metafora 'killed' dibandingkan bentuk-bentuk lain dengan makna yang sama karena penulis ingin memberikan vitalitas dan greget pada teks. Penulis tidak hanya ingin memberikan informasi, akan tetapi juga ingin memberi dampak emotif kepada pembaca. Ini harus dipertahankan dalam teks terjemahannya. Ia beranggapan bahwa dalam menerjemahkan sebuah teks, tidak hanya informasi yang harus ditransfer, tetapi soal rasa juga harus dipertimbangkan. Ia berkata demikian karena selama ini ia terbiasa bermain di area rasa bahasa. Maklumlah, ia seorang pujanga. Selain menulis puisi, ia juga sering menerjemahkan puisipuisi yang ditulis dalam bahasa asing ke dalam bahasa Indonesia. Jadi sangatlah bisa diterima jika dia menerjemahkan dengan cara demikian.

\section{METODE PENELITIAN}

Artikel disusun berdasarkan studi pustaka dari beberapa sumber primer dan sekunder yang terkait dengan penjelasan arti, kritik, dan penilaian terjemahan.

\section{HASIL DAN PEMBAHASAN}

\section{Kritik Terjemahan}

Ilustrasi di atas hanyalah sebuah pintu masuk menuju apa yang disebut dengan Kritik Terjemahan. Newmark meyatakan bahwa kritik terjemahan adalah sesuatu yang menyenangkan (Newmark,1988). Terlebih jika kita mengkritik hasil terjemahan dari dua orang yang berbeda dengan teks asli yang sama. Kritik Terjemahan merupakan jembatan yang menghubungkan antara Teori Terjemahan dengan Praktik Terjemahan.

Dalam membuat sebuah kritik terhadap sebuah terjemahan (baca: hasil terjemahan), seorang kritikus selain menganalisis teks terjemahan berdasarkan kemampuan kognitifnya, dia juga akan bermain-main di area rasa bahasa. Dalam artikel ini akan dijabarkan secara ringkas berbagai hal yang terkait dengan kritik terjemahan. Mari kita mulai dengan satu hal yang kemungkinan besar merupakan hal yang terpenting dalam kritik terjemahan. Banyak aspek yang dilibatkan dalam membuat sebuah kritik, namun seorang kritikus seharusnya berangkat dari satu hal yang paling penting, yaitu sikap. Sikap seorang kritikus.

Dalam mengevaluasi terjemahan, seorang kritikus tidak terlalu melihat pada seberapa bagus sebuah hasil terjemahan, walaupun hal tersebut tentu juga menjadi salah satu pertimbangan. Namun seorang kritikus cenderung lebih melihat kepada mengapa seorang penerjemah, misalnya, cenderung menerjemahkan ke dalam bentuk yang lebih netral sedang penerjemah yang lain lebih cenderung kepada bentuk yang melibatkan emosi. Inilah yang dimaksud dengan sikap. Sikap adalah landasan utama bagi seorang kritikus.

Selain sikap, maka hal penting lain yang akan bermain di area kritik terjemahan adalah tentu saja kemampuan seorang kritikus dalam menganalisis fenomena yang tertuang dalam sebuah terjemahan, misalnya tentang metode penerjemahan, prosedur penerjemahan, tujuan penulis, kelompok pembaca, dan lain sebagainya. 


\section{Menilai Terjemahan sebagai Salah Satu Aspek dalam Kritik Terjemahan}

Sebelum beranjak lebih jauh dengan pembahasan tentang langkah-langkah umum dalam membuat sebuah kritik, maka ada baiknya bila kita ketahui perbedaan antara menilai terjemahan dan membuat kritik terjemahan. Menilai terjemahan dan membuat kritik terjemahan adalah sesuatu yang berbeda. Meski demikian, ada benang merah yang bisa ditarik antar keduanya. Ini adalah sesuatu yang sangat wajar karena salah satu yang menjadi dasar dari kemampuan membuat kritik adalah kemampuan membuat sebuah penilaian terhadap sebuah terjemahan. Seseorang tidak akan membuat kritik sebuah terjemahan sebelum dia mengenal dasar-dasar dalam membuat sebuah penilaian terhadap sebuah terjemahan.

Dalam menilai sebuah terjemahan maka ada dua hal yang akan selalu dilihat, yaitu kebenaran dan kesalahan. Namun pada kesempatan ini hanya akan dibahas sisi kesalahan saja dengan asumsi sekaligus membahas tentang kebenaran jika kita menarik nilai kebalikkanya.

Newmark menyodorkan dua kriteria kesalahan dasar (Newmark, 1988). Pertama adalah kesalahan referensial dan yang kedua adalah kesalahan linguistik. Kesalahan referensial adalah yang berkaitan dengan fakta atau kebenaran universal.

Contoh dari kesalahan referensial adalah: kereta api berjalan di air; buah menumbuhkan akar; rumah terbuat dari kertas

Bentuk-bentuk di atas adalah salah secara referensial, meskipun dalam kondisi yang sangat khusus bisa dibenarkan sebagai sebuah metafora yang berkaitan dengan konteks wacana. Namun dalam bahasa normal atau bahasa non-kiasan, bentuk-bentuk di atas adalah salah. Artinya, jika dalam sebuah terjemahan kita menemui bentuk demikian, maka kemungkinan besar terjemahan tersebut adalah salah.

Kesalahan referensial biasanya terjadi dikarenakan kurangnya pengetahuan dan wawasan penerjemah tentang topik yang diusung teks. Oleh karena itulah maka Newmark (1988) menyatakan bahwa seorang penerjemah sebaiknya adalah seorang spesialis. Seorang penerjemah hanya menerjemahkan teks-teks jenis tertentu yang memang benar-benar ia kuasai untuk menghindari kesalahan referensial.

Jenis kesalahan berikutnya adalah kesalahan linguistik, yaitu kesalahan dalam mengartikan sebuah bentuk sebagai akibat dari: (a) lemahnya penguasaan bahasa sumber dan bahasa sasaran, (b) lemahnya ketrampilan dalam penggunaan kamus, (c) serta buruknya kualitas kamus yang dijadikan alat bantu penerjemahan.

\section{Kesalahan Linguistik dan Sumber Pemicunya}

Banyak hal yang berpotensi mengundang kesalahan penerjemahan jika penerjemah tidak memiliki pengetahuan dan pemahaman yang memadai tentang bahasa sumber dan bahasa sasaran. Kesalahan linguistik salah satunya berasal dari lemahnya pengetahuan tentang makna dan bentuk, baik pada bahasa sumber maupun pada bahasa sasaran. Bentuk-bentuk yang bisa menjadi pemicu kesalahan sangatlah banyak dan beragam, misalnya saja yang berkaitan dengan makna sekunder serta betuk kolokasi.

Di dalam semantik terdapat dikotomi makna primer dan makna sekunder. Kekurangpahaman tentang makna sekunder sebuah kata berpotensi menghasilkan kesalahan linguistik dalam penerjemahan, dan mungkin juga kesalahan referensial.

Berikut adalah sebuah contoh tentang dinamika makna primer dan makna sekunder pada bentuk "run" dalam Bahasa Inggris yang berpotensi menimbulkan kesalahan penerjemahan (Larsen, 1984): 
- The boy runs

- The car runs

- $\quad$ The eye runs

- The tap runs

- The paint runs

Selain makna sekunder, satu contoh lain yang berpotensi mengundang kesalahan dalam penerjemahan terkait dengan lemahnya penguasaan bahasa sumber dan bahasa sasaran adalah pada bentuk-bentuk kolokasi.

Bentuk 'to catch a bus' tentu tidak diterjemahkan dengan 'menangkap bis' dan bentuk 'to deliver a verdict' tentu akan salah jika diterjemahkan dengan 'mengirimkan sebuah putusan' karena bertentangan dengan kolokasi dalam Bahasa Indonesia yang benar yaitu 'menetapkan sebuah putusan'. Mari kita lihat contoh tentang dinamika kolokasi dalam bahasa Inggris yang berpotensi melahirkan kesalahan dalam penerjemahannya (Baker, 1992). Verba 'delivery' berkolasi dengan beragam nomina:

- deliver a letter

- deliver a blow

- deliver a speech

- deliver a verdict

- deliver a baby

Jika seseorang tidak memiliki pengetahuan dan pemahaman yang memadai tentang Bahasa Inggris dan Bahasa Indonesia, maka kemungkinan ia akan salah dalam menerjemahkan bentuk-bentuk kolokasi yang ada dalam contoh di atas dan ini masuk ke dalam kategori kesalaan linguistik.

\section{Kerangka Kritik}

Menurut Newmark tedapat banyak hal yang perlu diperhatiakan jika kita akan atau sedang membuat kritik tentang sebuah hasil terjemahan (Newmark, 1988). Hal-hal tersebut adalah:

- Analisis singkat terhadap teks Bahasa Sumber

- Aspek tujuan dan fungsi teks asli

- Interpretasi penerjemah terhadap tujuan teks asli

- Metode penerjemahan yang digunakan

- Kelompok pembaca dari teks terjemahan

- Perbandingan teks reprsentatif antara teks asli dengan teks terjemahan

- Evaluasi terhadap terjemahan

Secara garis besar hal-hal tersebut diatas bisa direalisasikan ke dalam langkah-langkah umum membuat sebuat kritik terjemahan. Tahap yang paling awal adalah menganalisis teks. Penganalisisan terhadap teks menyangkut tujuan penulis, karakter kelompok pembaca serta tentang kategori dan jenis teks. Dalam teks-yang berupa buku pedoman, buku teks akademis, dan sebagainya, beberapa hal sangat jelas ditangkap karena dinyatakan secara jelas oleh penulisnya di halaman pengantar. Jenis teks yang digunakan juga jelas, biasanya adalah informatif atau vokatif teks. Sebagai catatan, teks jenis informatif dan vokatif biasanya diterjemahkan dengan pendekatan atau metode literal dan komunikatif.

Termasuk ke dalam tahap ini adalah analisis skala stilistika. Ragam stilistika apa saja yang sering muncul dalam teks asli serta bagaimana penerjemah memperlakukan ragam stilistika yang ada di dalam teks. Novel biasanya memiliki ragam srikilistika yang lebih kaya dibanding dengan teks jenis lain. 
Langkah berikutnya adalah melihat tujuan penerjemah. Tujuan penerjemah biasanya pararel dengan tujuan penulis teks asli serta kelompok pembaca teks asli dan teks terjemahan, walaupun tidak selalu demikian. Pada tahap ini kritikus berusaha untuk mengetahui beberapa hal terkait dengan penerjemah, dan jika memungkinkan melakukan wawancara dengan si penerjemah. Kritikus akan berusaha sebisa mungkin untuk benar-benar memahami tidak hanya pikiran penulis, akan tetapi juga alam pikiran penerjemah. Ilustrasi yang tertuang di awal tartikel ini adalah sedikit gambaran tentang alam pikiran penerjemah.

Dalam tahap ini juga terdapat satu area yang disebut dengan ideologi penerjemah. Jika situasi benar-benar memungkinkan dan mengijinkan, seorang kritikus akan masuk ke dalam satu area yang disebut dengan ideologi penerjemah, walaupun mungkin ini adalah satu hal yang cukup sulit untuk dilakukan kecuali kritikus mempunyai akses langsung ke penerjemah.

Tahap ketiga adalah membandingkan teks asli dengan tekas terjemahan. Kita bisa mengambil klasifikasi perbandingan seperti berdasarkan bentuk metafora, neologisme, modulasi, parafrase, kata budaya, tingkatan bahasa, ambuguitas dan lain sebagainya. Dengan demikian pengevaluasian juga akan merambah ke prosedur penerjemahan yaitu bagaimana seorang penerjemah memilih prosedur tertentu untuk mengatasi kendala yang muncul dalam proses penerjemahan.

Data dari teks asli yang berupa bentuk yang sudah diklasifikasi dibandingkan dengan bentuk terjemahannya. Pada tahap ini sekilas mirip dengan menilai sebuah terjemahan. Perbedaannya adalah bahwa di sini seorang kritikus tidak berhenti kepada jenjang "salah-benar", akan tetapi ia melanjutkan kepada pengevaluasian yang lebih mendalam seperti mengapa dalam menghadapi teks seperti "Science has characterized this century" seorang penerjemah lebih memilih untuk menerjemahkannya dengan bentuk "Ilmu pengetahuan telah menjadi ciri abad ini" dibanding bentuk misalnya "Ilmu pengetahuan mencirikan abad ini" atau bentuk yang lebih sederhana seperti "Ilmu pengetahuan adalah ciri abad ini". Atau bentuk metafora seperti "Your car has wings" diterjemahkan menjadi "Lari mobilmu seperti setan" dibandingkan dengan bentuk "Mobilmu melaju sangat kencang" ,dan lain sebagainya. Tahap ini adalah tahap yang paling penting dalam membuat sebuah kritik (Newmark, 1988) dan sekaligus mungkin merupakan tahap yang paling menyenangkan.

Tahap terakhir adalah mengevaluasi terjemahan. Seorang kritikus akan mengkaji keakuratan referensial dan keakuratan pragmatik dari teks terjemahan. Untuk bisa mengevaluasi keakuratan referensial, maka tentu saja kritikus juga memiliki bekal yang cukup tentang topik yang dibahas dalam teks asli. Oleh karena itulah maka seorang kritikus, seperti halnya seorang penerjemah, idealnya adalah juga seorang spesialis. Dengan demikian dia benar-benar memiliki bekal yang kuat di dalam melakukan evaluasi terjemahan.

\section{Kritik Terjemahan dalam Dimensi Pendidikan}

Hal terakhir yang juga terkait dengan kritik terjemahan adalah posisi kritik terjemahan di dalam ranah pendidikan, dalam hal ini tentu saja adalah pendidikan bahasa. Kritik Terjemahan bisa dijadikan satu program yang diharapkan mampu memberi keuntungan bagi berbagai elemen yang secara langsung maupun tak langsung terlibat di dalam pendidikan. Singkat kata, sebagai bagian dari sebuah program pendidikan, belajar dan berlatih membuat sebuah Kritik Terjemahan bisa mendatangkan keuntungan sebagai berikut: memperluas pengetahuan dan pemahaman kita tentang bahasa sumber dan bahasa sasaran; meningkatkan kompetensi kita sebagai seorang mahasiswa bahasa, seorang guru bahasa, seorang guru penerjemahan atau seorang penerjemah; meningkatkan kemampuan kita dalam mengatasi masalah yang timbul dalam menerjemahkan sebuah teks; dan memperluas pengetahuan dan pemahaman kita tentang topik yang diusung oleh teks. 


\section{SIMPULAN}

Ada beberapa hal yang mungkin bisa menjadi catatan dalam penyajian ini. Pertama adalah telah kita ketahui bersama bahwa kritik terjemahan adalah jembatan yang menghubungkan antara teori terjemahan dengan praktik terjemahan. Kedua adalah bahwa seorang kritikus lazimnya memulai sebuah kritik dengan sebuah sikap, yaitu sikap seorang seorang kritikus, dan dia juga harus mempunyai bekal pengetahuan yang cukup untuk bisa membuat sebuah kritik terjemahan. Ketiga adalah bahwa dalam membuat sebuah kritik, seorang kritikus tidak melakukan koreksi dan jastifikasi terhadap sebuah terjemahan. Akan tetapi mempelajari dan mengkaji sebuah hasil terjemahan yang pada akhirnya akan mengantar dia kepada sebuah pemahaman dan dia mampu menjelaskan mengapa sebuah hasil terjemahan bisa menjadi seperti yang ada ditinjau dari beberapa aspek seperti metode, prosedur, tujuan penulis, tujuan penerjemah, kelompok pembaca dan lain sebagainya. Terakhir adalah bahwa memasukkan Kritik Terjemahan ke dalam program pendidikan bahasa akan mampu memberikan keuntungan-kuntungan positif bagi berbagai pihak yang terkait.

\section{DAFTAR PUSTAKA}

Baker, M. (1992). In Other Words. London: Routledge.

Larson, M. (1984). Meaning-Based Translation. London: University Press of America.

Newmark, P. (1988). A Textbook of Translation. United Kingdom: Prentice Hall International. (1991). About Translation. England. 